\title{
Testing the Asymmetric Response of China's Stock Returns to Oil Price Dynamics: Does Fear of COVID-19 Matter?
}

\author{
Joel Ede Owuru' $\oplus^{\text {a }}$ \\ 1 Department of Economics, Augustine University, Ilara-Epe, Lagos State, Nigeria \\ Keywords: global fear index, oil price, stock return, linear ardl, nonlinear ardl \\ https://doi.org/10.46557/001c.24139
}

\section{Asian Economics Letters}

Vol. 2, Issue 3, 2021

\begin{abstract}
This study investigates the response of Chinese stock returns to oil prices amidst the COVID-19 pandemic using both linear and nonlinear autoregressive distributed lag (ARDL) models. The results indicate that oil price and the COVID-19 Global Fear Index (GFI), respectively, affect stock returns positively and negatively in the short run. While oil price asymmetry matters, Chinese stock returns do not respond to oil price changes and GFI in the long run.
\end{abstract}

\section{Introduction}

This paper examines how Chinese stock returns, using the Shanghai Composite Stock Price Index, respond to oil price dynamics amidst the COVID-19 pandemic. The main hypothesis is that, given fear of COVID-19, stock market returns in China respond asymmetrically to shocks in the oil price. The theoretical premise or framework that motivates this proposed oil-stock-COVID-19 linkage is the Arbitrage Pricing Theory (APT) proposed by Ross (1976). This theory allows inclusion of indicators of systemic risk, such as the COVID-19 Global Fear Index (GFI) and macroeconomic variables like oil price, in predicting expected returns of assets (Haynes, 2020; Iyke \& Ho, 2021).

Testing this hypothesis is topical because China is globally recognized as a major oil importer (Hu et al., 2018). Further, as a strong emerging market economy, China's stock market outcomes may be responsive to the dynamics of oil price in the post-COVID-19 era.

There is existing work on the oil-stock nexus (see Basher \& Sadorsky, 2006; Fayyad \& Daly, 2011; Lin et al., 2014; Narayan \& Narayan, 2010; Salisu \& Isah, 2017, among others). The COVID-19 pandemic has caused global supply chain disruptions, loss of human resources, and recurring economic and financial shocks (see Salisu \& Sikiru, 2020; Zhang et al., 2020, for example), with negative impacts on stock returns in 64 countries (Ashraf, 2020) and for 1,579 firms in China (Alfaro et al., 2020).

The present study employs daily time series of Shanghai Composite stock prices, oil prices, and GFI covering the period from February 10, 2020 to January 10, 2021, and finds that, as panic due to the pandemic rises, stock returns are dampened, while changes in the oil price affect stock returns in the short run. ${ }^{1}$

Three research gaps are filled with these findings. First, GFI is a new measure of pandemic-caused panic constructed by Salisu \& Akanni (2020), and its empirical testing is scarce. Second, previous studies do not explore the predictive importance of the GFI index, apart from Salisu, Akanni, et al. (2020), who test the predictive power of this index over commodity price returns. Third, this study uses a countryspecific approach instead of a panel approach (see Salisu, Ebuh, et al., 2020), allowing us to explore country-specific effects.

This paper proceeds as follows. The data and methodology are presented in Section II. Section III describes the results obtained and the conclusion drawn. Finally, Section IV details applicable policy prescriptions.

\section{Data and Methodology}

\section{A. Data}

Stock index and oil price data are taken from [www.investing.com]. Two variants of crude oil price (BRENT and $W T I$ ) are used. GFI captures the extent of panic (fear) associated with the COVID-19 outbreak. The numbers of global daily infections and deaths are used to construct this index. ${ }^{2}$ The choice of sample size is based on data availability, especially GFI, at the time of estimation. The data are cleaned to have the same time dimension for all series.

\footnotetext{
a Corresponding author email: joel.owuru@augustineuniversity.edu.ng

1 These results were subjected to robustness tests, and the results, especially the CUSUM and CUSUM square plots, are available upon request.

2 The earlier version of the data is contained in Mendeley with a caption "Salisu and Akanni (2020). Global Fear Index Data for the COVID-19 Pandemic [http://dx.doi.org/10.17632/yhs329pd7d.1]" while the updated version can be found in the authors' links in Researchgate.
} 
Table 1: Descriptive Statistics

\begin{tabular}{lcccc}
\hline Statistics & SSR & WTI & BRENT & GFI \\
\hline Mean & 0.042 & 37.859 & 40.364 & 56.479 \\
Median & 0.048 & 40.510 & 42.780 & 52.420 \\
Maximum & 3.278 & 53.770 & 59.720 & 91.190 \\
Minimum & -1.999 & -36.980 & 9.120 & 9.909 \\
Standard Dev. & 0.552 & 10.588 & 10.388 & 12.347 \\
Relative S. Dev & 13.143 & 0.280 & 0.257 & 0.219 \\
Skewness & 0.458 & -2.304 & -0.884 & 1.243 \\
Kurtosis & 9.072 & 13.754 & 3.369 & 5.204 \\
Observations & 217 & 217 & 217 & 217 \\
\hline
\end{tabular}

This table reported selected descriptive statistics to understand our dataset. The relative standard deviation is obtained as standard deviation divided by the mean of each variable.

\section{B. Model Specifications}

Motivated by the APT framework, the stochastic model is, therefore, specified as:

$$
S S R_{t}=a+b_{1} O I L_{t}+b_{2} G F I+\epsilon_{t}
$$

where $\operatorname{SSR}_{t}$ is Shanghai Composite stock returns, $O I L$ is crude oil price, and GFI is as already defined. ${ }^{3}$ While $a$ denotes the intercept of the model, $b_{1}$ and $b_{2}$ represent the coefficients of the independent variables. The time dimension of the series is $t$ while $\epsilon$ is the error term. Stock returns ( $S S R)$ are measured as 100 per cent of differential change $(\Delta$ ) in the logarithmic values of the Shanghai Composite stock price (SSP). That is:

$$
S S R_{t}=100(\Delta \log S S P)
$$

Having pre-established that the series exhibit different orders of integration (see Table 2), the autoregressive distributed lag (ARDL) framework of Pesaran et al. (2001) is followed for the linear model and is specified as:

$$
\begin{aligned}
\Delta S S R_{t}= & \alpha+\sum_{k=1}^{n} \beta_{t-k} \Delta S S R_{t-k} \\
& +\sum_{k=0}^{n} \delta_{t-k} \Delta O I L_{t-k} \\
& +\sum_{k=0}^{n} \pi_{t-k} \Delta G F I_{t-k} \\
& +\lambda_{1} S S R_{t-k}+\lambda_{2} O I L_{t-k} \\
& +\lambda_{3} G F I_{t-k}+\varepsilon_{t}
\end{aligned}
$$

In Equation (3), $k$ denotes the optimal lag length, while variables with (without) $\Delta$ are for the dynamic short-run (long-run) coefficients. In addition to the linear ARDL in Equation (3), it is important to account for nonlinear cointegration (NARDL) of the variables following the Shin et al (2014) approach by decomposing oil price into positive and negative shocks ${ }^{4}$ as shown in Equations (4) and (5).

$$
O I L_{t}^{+}=\sum_{j=1}^{t} \Delta O I L_{j}^{+}=\sum_{j=1}^{t} \max \left(\Delta O I L_{j}, 0\right)
$$

$$
O I L_{t}^{-}=\sum_{j=1}^{t} \Delta O I L_{j}^{-}=\sum_{j=1}^{t} \min \left(\Delta O I L_{j}, 0\right)
$$

By incorporating Equations (4) and (5) into (3), the NARDL model is stated as:

$$
\begin{aligned}
\Delta S S R_{t}= & \alpha+\sum_{k=1}^{n} \beta_{t-k} \Delta S S R_{t-k} \\
& +\sum_{k=0}^{n} \pi_{t-k}^{+} \Delta O I L_{t-k}^{+} \\
& +\sum_{k=0}^{n} \pi_{t-k}^{-} \Delta O I L_{t-k}^{-} \\
& +\sum_{k=0}^{n} \theta \Delta G F I \\
& +\lambda_{1} S S R_{t-k}+\lambda_{2} O I L_{t-k}^{+} \\
& +\lambda_{3} O I L_{t-k}^{-}+\lambda_{4} G F I_{t-k}+\varepsilon_{t}
\end{aligned}
$$

where $O I L^{+}$, and $O I L^{-}$are the partial sum decomposed positive and negative changes in oil price, and $\pi^{+}$and $\pi^{-}$ represent their short-run coefficients. It is assumed that the value of the estimate of $\sum \pi_{k}^{+}$differs from the estimate of $\sum \pi_{k}^{-}$. Otherwise, there would be no evidence of asymmetries.

\section{Result and Discussion}

From Table 1, GFI exhibits its highest average value (56.5\%), followed by BRENT at $\$ 40.40$ per barrel, WTI at $\$ 37.90$ per barrel, and stock returns $(0.042 \%)$. Stock returns record the highest variation. The variables show a mixture of different orders of integration (Table 2, Panel A). With respect to structural break unit root, Table 2 (Panel B) reveals that while BRENT is non-stationary at levels with break dates, other variables ( $S S R$, WTI, and GFI) are stationary at levels regardless of breaks.

While WTI insignificantly predicts Shanghai stock returns for the study period as shown in the main results of Table 4, BRENT does significantly predict it in the nonlinear short-run model. GFI significantly reduces Chinese stock returns in the short run. Hence, if the level of panic

\footnotetext{
3 See Salisu \& Akanni (2020) for further description of GFI.

4 The Brock-Dechert-Scheinkman (BDS) test for nonlinearity shown in Table 3b provides further justification for the nonlinear model.

5 Narayan and Popp (2010), however, emphasize two breaks. However, only one break date could be identified in each of the two-break models in Table 2 (Panel B).
} 
Table 2: Unit Root Test Results

Panel A: Augmented Dickey Fuller (ADF) and Phillips-Perron (PP) tests

\begin{tabular}{|c|c|c|c|c|c|c|c|c|}
\hline \multirow[t]{2}{*}{ Variables } & \multicolumn{3}{|c|}{ Augmented Dickey Fuller } & & & \multicolumn{3}{|c|}{ Phillips-Perron } \\
\hline & $\begin{array}{c}\mathrm{t}- \\
\text { statistic }\end{array}$ & P-Value & Remark & & & $\begin{array}{c}\mathrm{t}- \\
\text { statistic }\end{array}$ & P-Value & Remark \\
\hline$S S R$ & -13.719 & $0.000^{*}$ & $\mathrm{I}(1)$ & & & -13.696 & $0.000^{*}$ & $I(1)$ \\
\hline BRENT & -13.887 & $0.000^{*}$ & $\mathrm{I}(1)$ & & & -13.936 & $0.000^{*}$ & $I(1)$ \\
\hline WTI & -14.948 & $0.000^{*}$ & $\mathrm{I}(1)$ & & & -3.780 & $0.019^{* *}$ & $\mathrm{I}(0)$ \\
\hline GFI & -2.889 & $0.048^{* *}$ & $\mathrm{I}(0)$ & & & -4.338 & $0.003^{*}$ & $\mathrm{I}(0)$ \\
\hline \multicolumn{9}{|c|}{ Panel B: Structural break unit root test results } \\
\hline Variables & \multicolumn{2}{|c|}{ SSR } & \multicolumn{2}{|c|}{ BRENT } & \multicolumn{2}{|c|}{ WTI } & \multicolumn{2}{|c|}{ GFI } \\
\hline \multirow{2}{*}{$\begin{array}{l}\text { Break types } \\
\text { and their T- } \\
\text { stat. }\end{array}$} & 10 & $\mathrm{AO}$ & $\mathrm{I}(\mathrm{O})$ & $A(O)$ & $\mathrm{I}(\mathrm{O})$ & $A(O)$ & $\mathrm{I}(\mathrm{O})$ & $A(0)$ \\
\hline & $-15.763^{*}$ & $-15.843^{*}$ & -4.329 & -3.872 & $-7.071^{*}$ & $-7.789^{*}$ & $-4.983^{* *}$ & $-5.014^{* *}$ \\
\hline $\begin{array}{l}\text { Break date } 1 \\
\text { (TB1) }\end{array}$ & $\begin{array}{l}6^{\text {th July, }} \\
2020\end{array}$ & $\begin{array}{l}6^{\text {th }} \text { July, } \\
2020\end{array}$ & $\begin{array}{c}5^{\text {th }} \\
\text { March, } \\
2020\end{array}$ & $\begin{array}{c}7^{\text {th }} \\
\text { April, } \\
2020\end{array}$ & $\begin{array}{l}20^{\text {th }} \\
\text { April, } \\
2020\end{array}$ & $\begin{array}{c}26^{\text {th }} \\
\text { March, } \\
2020\end{array}$ & $\begin{array}{c}8^{\text {th }} \\
\text { April, } \\
2020\end{array}$ & $\begin{array}{c}8^{\text {th }} \\
\text { April, } \\
2020\end{array}$ \\
\hline \multicolumn{9}{|l|}{$\begin{array}{l}\text { Break date } 2 \\
\text { (TB2) }\end{array}$} \\
\hline Lag Length ( $k$ ) & 0 & 0 & 0 & 9 & 5 & 14 & 0 & 0 \\
\hline
\end{tabular}

The results are divided into two panels. Panel A has results from the ADF and PP tests, while Panel B has structural break unit root test results. The selected t-statistics were from models with a constant and a time trend are used except for GFI where the ADF test is performed on only a constant. Non-stationary and stationary series are denoted as I(1) and I(0), respectively. The models named IO and AO represent innovational and additive outliers respectively. Finally, *, and ** represent, respectively, statistical significance at the $1 \%$ and $5 \%$ levels.

(fear) over COVID-19 increases by 1 unit, Shanghai stock return would decline by $0.012 \%$ and $0.15 \%$ in the ARDL and NARDL short-run models, respectively. Oil price and GFI are, however, insignificant in the long run in both models, although a long-run rise in oil prices (WTI and BRENT) would potentially decrease stock returns linearly and increase stock returns nonlinearly. ${ }^{6}$

In addition, stock returns would be expected to increase in the long run despite increased GFI. Thus, GFI would matter less for investors in Chinese stocks in the long run, and as time decays, the health system would have increased its capacity to cope with the pandemic (see Alfaro et al., 2020 and Salisu \& Vo, 2020 for similar findings). There is a tendency, therefore, for rapid recovery from short-run shocks due to the pandemic (see the error correction terms).

Further, asymmetry matters in the oil-stock returns link post-COVID-19 in China (see the Wald test for asymmetry). The overall implication is that the response of China's stock market returns to oil price shocks amidst COVID-19 is a short-run phenomenon.

\section{Conclusion and Policy Prescriptions}

This paper investigates how China's stock returns have responded to oil price dynamics post-COVID-19. In the short run, changes in oil price (BRENT) predict stock returns positively, while GFI decreases stock returns. While oil price asymmetry matters, Chinese stock returns do not respond to changes in the oil price and GFI in the long run. Hence, the oil-stock-GFI linkage in China is a short-run phenomenon. Among possible policy alternatives, a comprehensive health policy that would aid speedy recovery from the shocks of the pandemic is necessary to strengthen high stock returns in China. Other researchers could focus on the oil-stock-COVID-19 linkage with structural breaks.

\section{Acknowledgement}

Helpful comments of the anonymous reviewers and the journal editor are acknowledged. No funding was received for this study.

Submitted: February 21, 2021 AEST, Accepted: April 29, 2021 AEST

\footnotetext{
6 Note that long-run results from dynamic models (including ARDL and VAR) are interpreted in reverse form of the accompanying statisti-
} cal signs of the estimated coefficients. 
Table 3: The Bound test and nonlinearity test results

\begin{tabular}{|c|c|c|c|c|c|}
\hline \multicolumn{6}{|c|}{ Panel A: Bounds test for cointegration } \\
\hline \multicolumn{3}{|c|}{$\begin{array}{l}\text { Linear ARDL (Symmetric) Model for WTI } \\
\text { Null: No long run relationship }\end{array}$} & \multicolumn{3}{|c|}{ Linear ARDL (Symmetric) Model for BRENT } \\
\hline Test Statistic & Value & k & Test Statistic & Value & $k$ \\
\hline F-statistic & 65.65 & 2 & F-statistic & 71.40 & 2 \\
\hline \multicolumn{3}{|c|}{ Pesaran et al. (2001) Critical value bounds } & \multicolumn{3}{|c|}{ Pesaran et al. (2001) Critical value bounds } \\
\hline Significance & $\mathrm{I}(0)$ & $\mathrm{I}(1)$ & Significance & $\mathrm{I}(0)$ & $\mathrm{I}(1)$ \\
\hline $1 \%$ & 6.34 & 7.52 & $1 \%$ & 6.34 & 7.52 \\
\hline $5 \%$ & 4.87 & 5.85 & $5 \%$ & 4.87 & 5.85 \\
\hline $10 \%$ & 4.19 & 5.06 & $10 \%$ & 4.19 & 5.06 \\
\hline \multicolumn{3}{|c|}{ Narayan (2004) Critical value bounds } & \multicolumn{3}{|c|}{ Narayan (2004) Critical value bounds } \\
\hline Significance & $\mathrm{I}(0)$ & $\mathrm{I}(1)$ & Significance & $\mathrm{I}(0)$ & $\mathrm{I}(1)$ \\
\hline $1 \%$ & 3.42 & 7.84 & $1 \%$ & 3.42 & 7.84 \\
\hline $5 \%$ & 2.23 & 5.43 & $5 \%$ & 2.23 & 5.43 \\
\hline $10 \%$ & 1.74 & 4.46 & $10 \%$ & 1.74 & 4.46 \\
\hline \multicolumn{3}{|c|}{$\begin{array}{l}\text { Nonlinear ARDL (Asymmetric) Model for WTI } \\
\text { Null: No long run relationship }\end{array}$} & \multicolumn{3}{|c|}{ Nonlinear ARDL (Asymmetric) Model for BRENT } \\
\hline Test Statistic & Value & $\mathrm{K}$ & Test Statistic & Value & $\mathrm{K}$ \\
\hline F-statistic & 51.24 & 3 & F-statistic & 54.75 & 3 \\
\hline \multicolumn{3}{|c|}{ Pesaran et al. (2001) Critical value bounds } & \multicolumn{3}{|c|}{ Pesaran et al. (2001) Critical value bounds } \\
\hline Significance & $\mathrm{I}(0)$ & $\mathrm{I}(1)$ & Significance & $\mathrm{I}(0)$ & $\mathrm{I}(1)$ \\
\hline $1 \%$ & 5.17 & 6.36 & $1 \%$ & 5.17 & 6.36 \\
\hline $5 \%$ & 4.01 & 5.07 & $5 \%$ & 4.01 & 5.07 \\
\hline $10 \%$ & 3.47 & 4.45 & $10 \%$ & 3.47 & 4.45 \\
\hline \multicolumn{3}{|c|}{ Narayan (2004) Critical value bounds } & \multicolumn{3}{|c|}{ Narayan (2004) Critical value bounds } \\
\hline Significance & $\mathrm{I}(0)$ & $\mathrm{I}(1)$ & Significance & $\mathrm{I}(0)$ & $\mathrm{I}(1)$ \\
\hline $1 \%$ & 3.30 & 7.01 & $1 \%$ & 3.30 & 7.01 \\
\hline $5 \%$ & 2.20 & 4.96 & $5 \%$ & 2.20 & 4.96 \\
\hline $10 \%$ & 1.75 & 4.14 & $10 \%$ & 1.75 & 4.14 \\
\hline \multicolumn{6}{|c|}{ Panel B: The BDS test results for nonlinearity } \\
\hline Variables & SSR & BRENT & WTI & GFI & \\
\hline Dimension & BDS Statistic & BDS Statistic & BDS Statistic & BDS Stati & \\
\hline 2 & $0.008(0.175)$ & $0.188(0.000)^{*}$ & $-4.23 \mathrm{E}-05(0.9446)$ & $0.168(0.0$ & \\
\hline 3 & $0.022(0.019)^{* *}$ & $0.319(0.000)^{*}$ & $-0.0001(0.9250)$ & $0.285(0.0$ & \\
\hline 4 & $0.029(0.010)^{*}$ & $0.408(0.000)^{*}$ & $-0.0003(0.9096)$ & $0.361(0.0$ & \\
\hline 5 & $0.032(0.006)^{* *}$ & $0.467(0.000)^{*}$ & $-0.0004(0.8962)$ & $0.410(0.0$ & \\
\hline 6 & $0.033(0.004)^{*}$ & $0.506(0.000)^{*}$ & $-0.0006(0.8841)$ & $0.439(0.0$ & \\
\hline
\end{tabular}

This table has two sets of results. Panel A has the results from the bounds test for cointegration, while Panel B has results on the BDS nonlinearity test. The unrestricted intercept and trend critical values of the bounds test are obtained from Pesaran et al. (2001) and Narayan (2004) based on the numbers of the regressors (k). Finally, * and ${ }^{* *}$ denote statistical significance at the $1 \%$ and $5 \%$ levels, respectively, and the p-values of the BDS statistics are in the parentheses. 
Table 4: The main regression results

\begin{tabular}{|c|c|c|c|c|}
\hline \multirow[t]{2}{*}{ Variable } & \multicolumn{2}{|c|}{ Linear or Symmetric (ARDL) Model } & \multicolumn{2}{|c|}{ Nonlinear or Asymmetric (NARDL) Model } \\
\hline & WTI & BRENT & WTI & BRENT \\
\hline \multicolumn{5}{|l|}{ Short run Coefficients } \\
\hline$\Delta(W T I)$ & $0.003(0.485)$ & & & \\
\hline$\Delta(W T I(+)$ & & & $0.001(0.696)$ & \\
\hline$\Delta(W T I(-)$ & & & $-0.001(0.691)$ & \\
\hline$\triangle(B R E N T)$ & & $0.084(0.000)^{*}$ & & \\
\hline$\Delta(B R E N T(+)$ & & & & $0.107(0.000)^{*}$ \\
\hline$\Delta(B R E N T(-)$ & & & & $0.110(0.000)^{*}$ \\
\hline$\Delta(G F I)$ & $-0.016(0.009)^{* *}$ & $-0.014(0.016)^{* *}$ & $-0.015(0.012)^{* *}$ & $-0.014(0.016)^{* *}$ \\
\hline ECT(-1) & $-0.954(0.000)^{*}$ & $-0.960(0.000)^{*}$ & $-0.979(0.000)^{*}$ & $-0.969(0.000)^{*}$ \\
\hline Wald test for Asymmetry & & & $1.178(0.310)$ & $9.717(0.000)^{*}$ \\
\hline \multicolumn{5}{|l|}{ Long run Coefficients } \\
\hline C & $0.069(0.804)$ & $-0.032(0.912)$ & $0.111(0.745)$ & $-0.075(0.7903)$ \\
\hline WTI & $0.003(0.484)$ & & & \\
\hline WTI(+) & & & $0.005(0.185)$ & \\
\hline WTI(-) & & & $-0.002(0.690)$ & \\
\hline BRENT & & $0.003(0.459)$ & & \\
\hline BRENT(+) & & & & $0.001(0.739)$ \\
\hline BRENT(-) & & & & $0.005(0.265)$ \\
\hline GFI & $-0.002(0.499)$ & $-0.001(0.818)$ & $-0.003(0.412)$ & $0.000(0.984)$ \\
\hline Wald test for Asymmetry & & & $0.088(0.767)$ & $8.940(0.000)^{*}$ \\
\hline \multicolumn{5}{|l|}{ Diagnostic statistics } \\
\hline Breusch-Godfrey LM test & $0.535(0.587)$ & $0.472(0.625)$ & $0.118(0.889)$ & $0.731(0.483)$ \\
\hline Breusch-Pagan Godfrey & $0.457(0.767)$ & $0.219(0.954)$ & $0.578(0.748)$ & $0.551(0.795)$ \\
\hline Ramsey Reset Test & $4.131(0.043)^{* *}$ & $3.069(0.081)^{* * *}$ & $4.698(0.031)^{* *}$ & $0.443(0.507)$ \\
\hline
\end{tabular}

This table reports the main regression results. Panel A has short-run coefficients, Panel B has long-run coefficients, and Panel C contains diagnostic test results. Finally, ****, and ${ }^{* * * *}$ denote statistical significance at the $1 \%, 5 \%$, and $10 \%$ levels, respectively, with probability values of the coefficients shown in the parentheses.

This is an open-access article distributed under the terms of the Creative Commons Attribution 4.0 International License (CCBY-SA-4.0). View this license's legal deed at https://creativecommons.org/licenses/by-sa/4.0 and legal code at https://creativecommons.org/licenses/by-sa/4.0/legalcode for more information. 


\section{REFERENCES}

Alfaro, L., Chari, A., Greenland, A. N., \& Schott, P. (2020). Aggregate and Firm-level Stock Returns during Pandemics, in Real Time [Working Paper No. 26950]. National Bureau of Economic Research. https://doi.or $\mathrm{g} / 10.3386 / \mathrm{w} 26950$

Ashraf, B. N. (2020). Stock markets' reaction to COVID-19: Cases or fatalities? Research in International Business and Finance, 54, 101249. http s://doi.org/10.1016/j.ribaf.2020.101249

Basher, S. A., \& Sadorsky, P. (2006). Oil price risk and emerging stock markets. Global Finance Journal, 17(2), 224-251. https://doi.org/10.1016/j.gfj.2006.04.001

Fayyad, A., \& Daly, K. (2011). The impact of oil price shocks on stock market returns: Comparing GCC countries with the UK and USA. Emerging Markets Review, 12(1), 61-78. https://doi.org/10.1016/j.emema r.2010.12.001

Haynes, A. (2020). What Is the Arbitrage Pricing Theory (APT)? https://www.investopedia.com/contributors/5 $\underline{3677 /}$

Hu, C., Liu, X., Pan, B., Chen, C., \& Xia, X. (2018). Asymmetric Impact of Oil Price Shock on Stock Market in China: A Combination Analysis Based on SVAR Model and NARDL Model. Emerging Markets Finance and Trade, 54, 1693-1705.

Iyke, B. N., \& Ho, S.-Y. (2021). Exchange rate exposure in the South African stock market before and during the COVID-19 pandemic. Finance Research Letters. htt ps://doi.org/10.1016/j.frl.2021.102000

Lin, C. C., Fang, R. C., \& Chen, H. P. (2014). The impact of oil price shocks on the returns in China's stock market. Emerging Markets Finance and Trade, 50(5), 193-205,

Narayan, P. K., \& Narayan, S. (2010). Modelling the impact of oil prices on Vietnam's stock prices. Applied Energy, 87(1), 356-361. https://doi.org/10.1016/j.apen ergy.2009.05.037

Pesaran, M. H., Shin, Y., \& Smith, R. J. (2001). Bounds testing approaches to the analysis of level relationships. Journal of Applied Econometrics, 16(3), 289-326. https://doi.org/10.1002/jae.616
Ross, S. A. (1976). The arbitrage theory of capital asset pricing. Journal of Economic Theory, 13(3), 341-360. ht tps://doi.org/10.1016/0022-0531(76)90046-6

Salisu, A. A., \& Akanni, L. O. (2020). Constructing a Global Fear Index for the COVID-19 Pandemic. Emerging Markets Finance and Trade, 56(10), 2310-2331. https://doi.org/10.1080/1540496x.2020.1 785424

Salisu, A. A., Akanni, L., \& Raheem, I. (2020). The COVID-19 global fear index and the predictability of commodity price returns. Journal of Behavioral and Experimental Finance, 27, 100383.

Salisu, A. A., Ebuh, G. U., \& Usman, N. (2020). Revisiting oil-stock nexus during COVID-19 Pandemic: Some preliminary results. International Review of Economics and Finance, 69, 280-294. http s://doi.org/10.1016/i.iref.2020.06.023

Salisu, A. A., \& Isah, K. O. (2017). Revisiting the oil price and stock market nexus: A nonlinear Panel ARDL approach. Economic Modelling, 66, 258-271. $\underline{\mathrm{htt}}$ ps://doi.org/10.1016/j.econmod.2017.07.010

Salisu, A. A., \& Sikiru, A. A. (2020). Pandemics and the Asia-Pacific Islamic Stocks. Asian Economics Letters, 1(1). https://doi.org/10.46557/001c.17413

Salisu, A. A., \& Vo, X. V. (2020). Predicting stock returns in the presence of COVID-19 pandemic: The role of health news. International Review of Financial Analysis, 71. https://doi.org/10.1016/j.irfa.2020.10154 $\underline{6}$

Shin, Y., Yu, B., \& Greenwood-Nimmo, M. (2014). Modelling Asymmetric Cointegration and Dynamic Multipliers in a Nonlinear ARDL Framework. In Festschrift in Honor of Peter Schmidt (pp. 281-314). Springer. https://doi.org/10.1007/978-1-4899-800 8-39

Zhang, D., Hu, M., \& Ji, Q. (2020). Financial markets under the global pandemic of COVID-19. Finance Research Letters, 36, 101528. https://doi.org/10.1016/ j.frl.2020.101528 